HortSCIENCE 25(8):935-937. 1990.

\title{
Whole-plant Response of Chrysanthemum to Uniconazole Foliar Sprays or Medium Drenches
}

\author{
Terri Woods Starman \\ Department of Plant and Soil Science, Southern Illinois University, \\ Carbondale, IL 62901 \\ Additional index words. ancymidol, daminozide, Dendranthema $\times$ grandiflorurn, \\ Chrysanthemum $\times$ morifolium, plant growth retardants, XE-1019
}

\begin{abstract}
Single and multiple sprays of uniconazole at $0,5,10$, or $20 \mathrm{mg}^{-1 i t e r}{ }^{-1}$ were compared with daminozide sprays at $2500 \mathrm{mg} \cdot \operatorname{liter}^{-1}$ applied twice for height control of Dendranthema xgrandiflorum (Ramat.) Kitamura (Chrysanthemum $\times$ morifolium Ramat.) 'Puritan' and 'Favor'. A single uniconazole spray at $20 \mathrm{mg} \cdot \mathrm{liter}^{-1}$ applied 2 weeks after pinching or two uniconazole applications at $10 \mathrm{mg}^{-1 i t e r}{ }^{-1}$ applied 2 and 4 weeks after pinching were as effective as daminozide for reducing height. Drenches of uniconazole at $0,0.025,0.05$, or $0.10 \mathrm{mg}$ a.i./pot were compared with ancymidol drenches at $0.45 \mathrm{mg}$ a.i./pot for controlling height of 'Bright Golden Anne'. Although ancymidol was more effective, a $0.10-\mathrm{mg}$ uniconazole drench adequately reduced height. Chemical names used: $\alpha$-cyclopropyl- $\alpha$-(4-methoxyphenyl))-5-pyrimidinemethanol (ancymidol); butanedioic acid mono(2,2-dimethylhydrazide) (daminozide); (E)-(s)-1-(4chlorophenyl)-4,4-dimethyl-2-(1, 2,4-triazol-1-yl)-pent-1-ene-3-ol (uniconazole).
\end{abstract}

Potted chrysanthemums are treated with growth retardants to maintain plant height in good proportion to the container size. Daminozide now is the most widely used growth retardant because it is easy to use and plant response is predictable (Crater, 1980). Ancymidol is also effective and may be applied as a spray or medium drench, whereas daminozide is effective only as a spray (Nelson, 1985).

During the recent decade, several new growth retardants, including uniconazole, have been shown to be effective in controlling height of pot chrysanthemum (Barrett et al., 1986; Larson and Thorne, 1987; McDaniel, 1983; Wilfret, 1988). However, before uniconazole can be used conveniently by growers, research to determine the con-

Received for publication 5 Sept. 1989. I thank the Chevron Chemical Co. for their support of this experiment; Paul Gibson, Dept. of Plant and Soil Science, Southern Illinois Univ., for assistance in data analysis; and Barbara Garrison and David Annis for technical assistance. The cost of publishing this paper was defrayed in part by the payment of page charges. Under postal regulations, this paper therefore must be hereby marked $a d$ vertisement solely to indicate this fact. centration response for various cultivars must be completed. The objective of this research project was to determine the effects of single- and multiple-spray and drench applications of uniconazole on medium- and tallgrowing chrysanthemum cultivars.

The medium-height 'Puritan' and 'Favor' chrysanthemums were selected to test their response to uniconazole foliar sprays. The tall-growing 'Bright Golden Anne' was selected to determine the effectiveness of drenches. Five rooted cuttings were planted per 1.8-liter plastic container using Pro-Mix BX (Premier Brands, New Rochelle, N.Y.) on 9 Sept. 1988. Plants were lighted nightly from 2200 to 0200 HR for 2 weeks. Plants were manually pinched and a natural shortday period began on 23 Sept. Plants were fertilized at each irrigation with $20 \mathrm{~N}-4.4 \mathrm{P}$ $16.6 \mathrm{~K}$, with $\mathrm{N}$ at $300 \mathrm{mg} \cdot \mathrm{liter}^{-1}$, for 2 months, after which fertilizer rate was reduced by onehalf for the final one-third of crop time. Plants were grown in a $24 / 18 \mathrm{C}$ (venting/night) glass greenhouse and in full sun after the $50 \%$ summer shading was removed from the greenhouse on 1 Oct.

Growth retardant sprays included uniconazole at 5 and $10 \mathrm{mg} \cdot$ liter $^{-1}$ applied on 7 Oct. 1988 (date 1), 2 weeks after the beginning 
Table 1. Effects of daminozide and uniconazole foliar sprays on 'Puritan' and 'Favor' chrysanthemum.

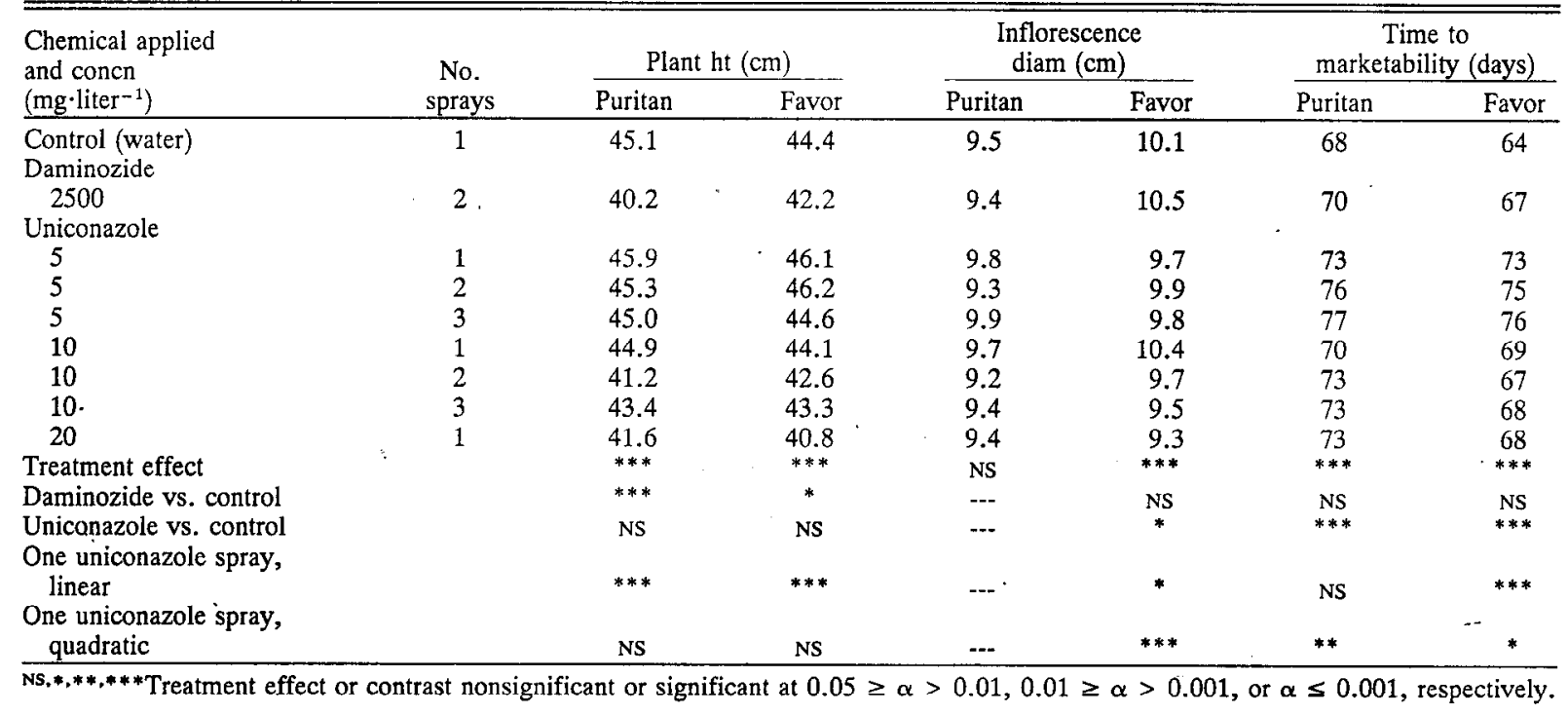

Table 2. Effects of ancymidol and uniconazole drenches on 'Bright Golden Anne' chrysanthemum.

\begin{tabular}{lccc}
\hline \hline $\begin{array}{l}\text { Chemical applied } \\
\text { and concn } \\
\text { (mg a.i./pot) }\end{array}$ & Plant ht $(\mathrm{cm})$ & $\begin{array}{c}\text { Time to } \\
\text { Inflorescence } \\
\text { diam }(\mathrm{cm})\end{array}$ & $\begin{array}{c}\text { Tirketability } \\
\text { (days) }\end{array}$ \\
\hline $\begin{array}{l}\text { Control (water) } \\
\text { Ancymidol }\end{array}$ & 58.0 & 12.2 & 71 \\
$\quad 0.45$ & & & 75 \\
Uniconazole & 47.1 & 11.4 & 72 \\
0.025 & 54.7 & 11.5 & 73 \\
0.05 & 51.7 & 11.0 & 74 \\
0.10 & 49.3 & 11.4 & $* *$ \\
Treatment effect & $* * *$ & $* * *$ & NS \\
Ancymidol vs. control & $* * *$ & $* *$ & NS \\
Uniconazole vs. control & $* * *$ & NS & NS \\
Uniconazole, linear & $* * *$ & NS & \\
Uniconazole, quadratic & NS & &
\end{tabular}

$\geq \alpha>0.001$, or $\alpha \leq 0.001$, respectively.

of the short-day period, and pinching, when regrowth was 4 to $5 \mathrm{~cm}$ long. A second application was made 14 days later (21 Oct., date 2) and a third one followed 14 days thereafter (4 Nov., date 3). Uniconazole was applied once at $20 \mathrm{mg} \cdot \mathrm{liter}^{-1}$ on 7 Oct. by spraying $204 \mathrm{ml}$ of solution evenly over 1 $\mathrm{m}^{2}$ of bench space.- The spray volume received by each pot at initial treatment time was $\approx 8 \mathrm{ml}$, based on a $23-\mathrm{cm}$ pot canopy diameter. The growth retardant used for comparison was daminozide at $2500 \mathrm{mg} \cdot \mathrm{liter}$ applied twice to runoff at dates 1 and 2. Control plants were sprayed once with water on the first spray date.

Growth retardant drenches included uniconazole at $0.025,0.05$, and $0.10 \mathrm{mg}$ a.i. applied in $125 \mathrm{ml}$ of water per pot. The commercial control was $0.45 \mathrm{mg}$ a.i. ancymidol applied in $178 \mathrm{ml}$ of water per pot. The different volumes-were used to conform to label recommendations. Control plants were all drenched with $125 \mathrm{ml}$ of water per pot. All drenches were applied coincident with the initial foliar spray treatments, but on separate plants.

Data taken included plant height, inflorescence diameter, and time to marketability.
Height was measured at marketability from the base of the pot to the top of the inflorescences. Inflorescence diameter was a mean of three inflorescences per plant selected randomly and measured when plants were judged marketable. Time tomarketability was determined as the number of days from planting until all inflorescences were approaching maturity without showing an open center. Each cultivar was in a single-factor experiment using five one-pot replicates and a completely randomized design. Data were subjected to one-way analysis of variance, and single degree-of-freedom contrasts were conducted for appropriate comparisons. Trend analysis coefficients were obtained from a table of unequally spaced treatment coefficients (Little and Hills, 1978).

Plant height was affected by treatment for both cultivars (Table 1). Daminozide resulted in shorter plants, but uniconazole did not. In addition, height reductions achieved with one spray of uniconazole were linear with increasing concentration. None of the treatments affected the inflorescence diameter of 'Puritan' plants. Uniconazole reduced inflorescence diameter for 'Favor', but daminozide did not. Uniconazole delayed time to marketability of both cultivars relative to the control, 2nd the response was quadratic for both (Table 1). Increased concentrations of uniconazole did not delay time to marketability of 'Favor' to as great an extent as did lower concentrations. Daminozide did not delay time to marketability.

All growth retardant drenches reduced the plant height of 'Bright Golden Anne', as compared to the controls (Table 2). Greatest height control was achieved with $0.45 \mathrm{mg}$ a.i. ancymidol and $0.10 \mathrm{mg}$ a.i. uniconazole per pot. Plant height decreased linearly with increasing concentration of uniconazole. Inflorescence diameter was less than for the controls for all growth retardant treatments (Table 2). Increasing uniconazole concentrations did not further reduce inflorescence diameter. Uniconazole did not delay marketability compared to controls, whereas ancymidol did (Table 2). Time required for plants to reach marketability did not differ with increasing uniconazole concentration.

A single spray of uniconazole at 20 mg.liter ${ }^{-1}$ applied once when postpinch breaks are 4 to $5 \mathrm{~cm}$ long was similar in effect to daminozide at $2500 \mathrm{mg} \cdot$ liter $^{-1}$ applied twice at 2-week intervals. Similar results also were obtained when uniconazole was applied twice at $10 \mathrm{mg} \cdot$ liter $^{-1}$. Concentrations of uniconazole that are effective on medium-height chrysanthemum cultivars in our geographical area are similar to those effective on a naturally shorter cultivar in the southern United States (Barrett et al., 1986) and higher than those effective on short or tall cultivars grown in more northern areas (McDowell and Holcomb, 1987). Although varying environmental conditions due to geographical area may affect application rates, other factors, such as time of year and cultivar reaction, also result in differential responses (Crater, 1980).

Drenches of $0.10 \mathrm{mg}$ a.i. uniconazole/pot applied to 'Bright Golden Anne' gave adequate height control. This result is in agreement with other studies using uniconazole on 'Bright Golden Anne' (Barrett et al., 1986; 
Larson and Thorne, 1987). Although height reductions achieved in this study were significant, further height control may be desirable commercially.

An interesting response found in this study was the decreased time to marketability for 'Favor' with increasing concentration of uniconazole. Growth retardants are thought to indirectly influence flowering of several floricultural crops by retarding vegetative growth (Larson, 1985).

An undesirable effect of uniconazole was delayed time to marketability of 'Puritan' and 'Favor'. In addition, inflorescence diameter of 'Bright Golden Anne' and 'Favor' was reduced with uniconazole, but, I believe, not damaged because inflorescences remained large and in proportion to the overall size of the plant.

\section{Literature Cited}

Barrett, J.E., M.E. Peacock, and T.A. Nell. 1986. Height control of exacum and chrysanthemum with paclobutrazol, XE-1019, flurprimidol and RSW-0411. Proc. Fla. State Hort. Soc. 99:254255.

Crater, G.D. 1980. Pot mums, p. 261-285. In: R.A. Larson (ed.). Introduction to floriculture. Academic, New York.

Larson, R.A. 1985. Growth regulators in floriculture, p. 399-481. In: J. Janick (ed.). Horticultural reviews. vol. 7. AVI, Westport, Conn.

Larson, R.A. and C.B. Thorne. 1987. A new growth regulator works on pot mums. N.C.
Flower Growers Bul. 31(1):1-6.

Little, T.M. and F.J. Hills. 1978. Agricultural experimentation: Design and analysis. Wiley, New York.

McDaniel, G.L. 1983. Growth retardation activity of paclobutrazol on chrysanthemum. HortScience 18:199-200.

McDowell, J..M. and E.J. Holcomb. 1987. The influence of XE-1019 on height of poinsettia (Euphorbia pulcherrima Willd. Ex Klotzsch) and chrysanthemum (Chrysanthemum $\times$ morifolium Ramat.). HortScience 22:61. (Abstr.)

Nelson, P.V. 1985. Chemical growth regulation. Greenhouse operation and management. Reston Publishing Co., Reston, Va. p. 378-408.

Wilfret, G.J. 1988. Effect of XE-1019 on height of containerized chrysanthemums. HortScience 23:163. (Abstr.) 